УДК 621.396 .6

\title{
ОПТИМИЗАЦИЯ РАЗМЕЩЕНИЯ ПЕЧАТНЫХ ПЛАТ ПРИ ТЕПЛОВОМ ПРОЕКТИРОВАНИИ БЛОКОВ С ЕСТЕСТВЕННЫМ ВОЗДУШНЫМ ОХЛАЖДЕНИЕМ
}

\author{
Г. Н. ШИЛО, Е. К. АРЕШКИН, Н. П. ГАПОНЕНКО \\ Запорожский национальный технический университет, \\ Украина, Запорожье, 69063, ул. Жуковского, 64
}

\begin{abstract}
Аннотация. Рассмотрено влияние размещения печатных плат на распределение температур в блоках радиоэлектронных аппаратов с естественным воздушным охлаждением. Моделирование распределения температур в блоке и исследование массогабаритных характеристик проводилось с помощью систем автоматизированного проектирования и инженерного анализа. Созданы упрощенные геометрическая и тепловая модели блока. Проанализированы особенности теплообмена в блоках радиоэлектронных аппаратов с естественным воздушным охлаждением. Разработан алгоритм оптимизации размещения печатных плат в блоках радиоэлектронных аппаратов с естественным воздушным охлаждением с учетом неравномерного распределения мощностей между платами. Предложенный алгоритм может быть использован как один из этапов оптимизации габаритных, несущих или массогабаритных показателей блока в случае, когда мощности в блоке распределены неравномерно.
\end{abstract}

Ключевые слова: тепловая модель; воздушное охлаждение; перфорация; компоновка; оптимизация; программные средства; системы инженерного анализа; моделирование

\section{1. ВВЕДЕНИЕ}

Тенденция развития современных электронных приборов неразрывно связана с проблемой обеспечения тепловых режимов. Это объясняется непрерывным ростом плотности рассеиваемой мощности, жесткими условиями эксплуатации и многообразием конструктивного исполнения приборов при постоянном стремлении максимально снизить габариты и массу аппаратуры $[1,2]$. В результате возникают недопустимые перегревы электрорадиоэлементов, которые превышают оговоренный в технических условиях диапазон рабочих температур [3]. Эксплуатация элементов вне этого диапазона приводит к значительному снижению их надежности и снижению надежности аппаратуры в целом.
Тепловые расчеты радиоэлектронных аппаратов традиционно выполнялись с использованием упрощенных математических моделей, приближенно описывающих механизмы теплопередачи $[4,5]$, в частности, с использованием приближенных значений коэффициента теплопроводности. Данный подход постепенно вытесняется компьютерным моделированием тепловых процессов в пакетах численного анализа. Это объясняется рядом причин, к которым относятся возможность непосредственной передачи трехмерной геометрической модели исследуемого объекта в расчетную программу, что повышает точность расчета и позволяет учитывать влияние конструктивных параметров на процессы теплопередачи [6,7].

Системы автоматизированного проектирования, основанные на численных методах, 


\section{БИБЛИОГРАФИЧЕСКИЙ СПИСОК}

1. Борисов Ю. И. Динамика радиоэлектроники / Ю. И. Борисов. - М. : Техносфера, 2007. - 403 с.

2. Григорьян С. Г. Конструирование электронных устройств систем автоматизации и вычислительной техники / С. Г. Григорьян. - М. : Феникс, 2007. $304 \mathrm{c}$.
3. Шимкович А. А. Проектирование несущих конструкций электронных устройств / А. А. Шимкович. - Минск : Адукацыя і выхаванне, 2003. - 308 с.

4. Роткоп Л. Л. Обеспечение тепловых режимов при конструировании радиоэлектронной аппаратуры / Л. Л. Роткоп, Ю. Е. Спокойный. - М. : Сов. радио, 1976. $-232 \mathrm{c}$

5. Дульнев Г. Н. Тепло- и массообмен в радиоэлектронной аппаратуре / Г. Н. Дульнев. - М. : Высш. шк., 1984. - 247 с.

6. Алямовский А. А. Инженерные расчеты в SolidWorks Simulation / A. А. Алямовский. - М. : ДМК Пресс, 2010. — 464 с.

7. Алямовский A. A. SolidWorks Simulation. Как решать практические задачи / А. А. Алямовский. СПб. : БХВ-Петербург, 2012. - 448 с.

8. Шило Г. Н. Исследование массогабаритных и тепловых характеристик блоков радиоэлектронной аппаратуры с естественным воздушным охлаждением / Г. Н. Шило, Е. К. Арешкин, Н. П. Гапоненко // Прикладная радиоэлектроника. - 2014. - Т. 13, № 4. C. 419-424.

9. Шило Г. Н. Дослідження масогабаритних і теплових характеристик герметичних блоків радіоелектронних апаратів / Г. Н. Шило, О. В. Сиротюк, О. Е. Савелло, Ю. А. Лопатка, Е. К. Арешкин, Н. П. Гапоненко // Радиоэлектроника. Информатика. Управление. - 2013. - № 2. - С. 30-33. - Режим доступа : http://ric.zntu.edu.ua/article/view/20716.

10. Гапоненко Н. П. Оптимизация объема герметичных блоков радиоэлектронной аппаратуры / Н. П. Гапоненко, О. В. Сиротюк, Е. В. Огренич, Ю. А. Лопатка, Е. К. Арешкин // Прикладная радиоэлектроника. - 2012. — Т. 11, № 3. - С. 155-158.

Поступила в редакцию ? 